of paradox and reduction in residual deformity. It reduces pain and allows humane sedation without fear of respiratory depression. If a trained medical and nursing staff and proper facilities-that is, a respiratory unit-are available, and they should be, the hazards of I.P.P.V. are negligible.

Though blood-gas analysis is not used as the main indication for I.P.P.V., it has been found to be of great value in the management of a patient on a ventilator. This is particularly so in the "difficult" patient-that is, one with chronic lung disease or a low compliance from any other cause. Here frequent adjustments of inspiratory flow rates and inflation pressures may be necessary to achieve adequate ventilation, and the results of blood analysis are then invaluable. It is also very useful in the interpretation of certain clinical signs. For example, if varying levels of consciousness are occurring, are these due to a concurrent head injury or to hypoxia and acidosis ? Or, if the patient's blood pressure is falling, is this due to excessive ventilation or hypovolaemia? In the patient with renal failure is the restlessness respiratory or renal in origin? In these situations blood-gas studies may be the only means of deciding.

As the management of the respiratory problems improves the mortality rate will depend more and more on the severity of the associated injuries. For this reason patients in this series have been classified according to the sites of injury-that is, thoracic only or thoracic together with other major injuries. Furthermore, as patients die from dysfunctions rather than injuries, we have attempted to quantitate these dysfunctions.

Ten patients died. In four of these (Cases 27, 31, 71, and 128) death resulted from dysfunctions which could not be influenced by I.P.P.V. Three deaths (Cases 125, 193, and 199) were due to failure of respiration with which I.P.P.V. with pure oxygen failed to cope. The remaining three deaths (Cases 57, 66, and 122) were due to multiple factors, of which respiratory dysfunction contributed its share.
It is impossible to compare the results in this series with the results of current authors (Reid and Baird, 1965 ; Lloyd et al., 1965 ; Campbell, 1966). The indications for I.P.P.V. are different, and, furthermore, the mortality rate will, in part, depend on the presence of other serious injuries-for example, head or abdominal visceral injuries. However, if the results of this series are compared with those recorded by Griffiths in 1960 a marked improvement in the mortality rate is obvious. This is largely due to the efficient management of the respiratory problem.

\section{Summary}

Sixty-four patients with severe crush injuries of the chest are reviewed. They have been classified according to the anatomical site of injury. The great majority of patients received I.P.P.V., the indications for this being on clinical rather than biochemical features-particularly the persistence of dyspnoea and paradoxical respiration after the correction of airway obstruction and collapse of the lung. Serious complications encountered included anaemia, gastrointestinal stasis, renal failure, electrolyte disorders, and respiratory infection. The overall mortality rate was $16 \%$. The value of I.P.P.V. in abolishing respiratory effort, effecting internal splinting of the chest wall, and reducing pain is emphasized.

\section{REFERENCES}

Avery, E. E., Mörch, E. T., and Benson, D. W. (1956). F. thorac. Surg., Bargh, W., and Slawson, K. B. (1965). Brit. F. Anaesth., 37, 574. Campbell, D. (1966). Ibid., 38, 298.

Griffiths, H. W. C. (1960).' F. roy. Coll. Surg. Edinb., 6, 13

Lloyd, J. W., Smith, A. C., and O'Connor, B. T. (1965). Brit. med. 3., $1,1518$.

Reid, J. M., and Baird, W. L. M. (1965). Ibid., 1, 1105.

Robson, J. S. (1966). "The Genesis of Acute Renal Failure," 2nd Symposium on Advanced Medicine. Proceedings of a conference Symposium on Advanced Medicine. Proceedings of a conference held at the Royal College of Physicians, London, 29
December 1965 , edited by J. R. Trounce. London. Windsor, H. M., and Dwyer, B. (1961). Thorax, 16, 3.

\title{
Insulin Resistance
}

\author{
W. G. OAKLEY,* M.D., F.R.C.P. ; VALERIE E. JONES, $\dagger$ PH.D., B.SC. ; A. C. CUNLIFFE $\ddagger$ M.D., F.C.PATH
}

Brit. med. F., 1967, 2, 134-138

Insulin resistance is usually defined as a state in which the daily insulin requirement exceeds 200 units for more than two days (Root, 1929 ; Joslin et al., 1959). We have used a somewhat narrower definition in the cases described below, and have restricted the term to diabetics whose daily insulin requirement exceeded 200 units, was not attributable to severe ketosis or infection, and persisted for longer than one week. The incidence of this state is difficult to ascertain, but it is undoubtedly low. Smelo (1948) collected a series of 54 cases of insulin resistance, and Shipp et al. (1965) reviewed 55 cases published since 1948 and described 34 cases seen in the Joslin Clinic between 1940 and 1960 ; the latter constituted $0.1 \%$ of the total number of diabetics seen during this period. An earlier paper (Oakley et al., 1959) presented the results of immunological and other studies in 13 cases of insulin resistance, in six of which treatment with prednisone was given; these have been followed up and are included in the present study together with 28 additional cases.

* Director, Diabetic Department, King's College Hospital, London S.E.5. † Former Research Assistant, Department of Bacteriology, King's College Hospital. Now at National Institute for Medical Research, Mill Hill, London N.W.7.

$\ddagger$ Professor of Bacteriology, University of London ; Bacteriologist, King’s College Hospital, London S.E.5.
Insulin resistance may be due to a number of different causes, some of which, such as ketosis, hormone antagonism, and infection, have long been recognized. The condition may also exist for no demonstrable reason. Field and Stetten (1956) demonstrated the presence of an antagonist in the alpha fraction of the serum globulin in severe ketosis. An antagonist to insulin has also been found by Vallance-Owen et al. (1958) in the albumin fraction of plasma from uncontrolled insulin-requiring diabetics and also from normal subjects. In the experimental field Young (1937) produced a degree of insulin resistance in the metahypophysial phase of the diabetes induced in dogs by administration of anterior pituitary extract ; the same state has been shown to follow the administration of growth hormone. In man human growth hormone may increase insulin requirement, but not to resistant levels (personal observation). An insulin antagonist, placental lactogen, has been shown by Kalkhoff et al. (1964) to be produced in increasing amounts during both normal and diabetic pregnancy; this may account not only for the progressive rise in insulin requirement generally observed in diabetic pregnancy, which may reach resistant levels, but also for its sudden fall after delivery. Insulin resistance may rarely be associated with severe liver disease, including haemochromatosis (Colwell and Weiger, 1956), generalized 
lipodystrophy (Lawrence, 1946), and pregnancy and menstruation (Hubble, 1954).

The role of antibody has received increasing attention since the demonstration that the serum of certain insulin-resistant diabetics will protect rabbits (Glen and Eaton, 1938) and mice (Lowell, 1942) against the hypoglycaemic action of insulin. Lowell (1944) showed that this neutralizing factor had many of the characters of an antibody, and Oakley et al. (1959) found insulin antibodies by a passive cutaneous anaphylaxis test in 11 out of 13 patients with insulin resistance. In 39 insulinresponsive diabetics antibodies were detected by this test in only two, one of whom had a history of previous episodes of high insulin requirement. However, when the more sensitive techniques of haemagglutination (Arquilla and Stavitsky, 1956; Yankelowitch et al., 1956) and binding of ${ }^{131}$ I-labelled insulin (Berson et al., 1956) are used, the majority of subjects can be shown to produce antibodies within a few weeks of treatment with exogenous insulin. Berson and Yalow (1957) found that the serum of insulin-resistant diabetics bound much more insulin than did that of insulin-responsive cases; this suggests that the difference in antibody formation in the resistant patient may be only quantitative, but qualitative differences also exist (Jones, 1963).

\section{Serological Methods}

Two methods were used for the detection and titration of insulin antibodies.

1. Passive Cutaneous Anaphylaxis (P.C.A.).-This assay depends on the property of certain antibodies to sensitize the skin of guinea-pigs in such a way that subsequent contact with the appropriate antigen, in this case insulin, results in a local anaphylactic reaction. Details of the method were described by Oakley et al. (1959). In a control series of 30 non-diabetics and 59 diabetics, without evidence of insulin resistance, the P.C.A. test gave negative results in all but two patients, both of whom had previously required large doses of insulin.

2. Haemagglutination.-The methods of erythrocyte sensitization and of antibody titration were essentially those of Arquilla and Stavitsky (1956). Insulin was coupled to fresh human group $\mathrm{O}$ cells by bis-diazotized benzidine, these cells being preferred to sheep red blood cells because the need for adsorption of serum by unsensitized red cells was obviated. Evidence for the specificity of these methods is given by Jones (1963).

\section{Serological Findings}

Insulin antibodies were found by P.C.A. in 29 of the 41 patients with insulin resistance described in this paper. In Table I the P.C.A. antibody titre is shown in relation to the maintenance dose of insulin. In 15 out of 17 patients receiving over 500 units daily the serum gave a titre of 9 or greater, compared with 11 out of 24 of those receiving smaller doses; titres over 27 were more often found in the highest dosage group (11 out of 17 compared with 4 out of 24).

TABLB I.-Relation of P.C.A. Antibodies to Insulin Requirement in 41 Resistant Diabetics

\begin{tabular}{|c|c|c|c|c|c|c|}
\hline \multirow{2}{*}{$\begin{array}{c}\text { Maintenance } \\
\text { Dose } \\
\text { (units/day) }\end{array}$} & \multicolumn{5}{|c|}{ P.C.A. Titre } & \multirow{2}{*}{ Total } \\
\hline & $<3$ & $3-$ & 9- & $27-$ & 81 & \\
\hline $\begin{array}{r}200-300 \\
301-500 \\
\text { Over } 500\end{array}$ & $\begin{array}{l}6 \\
4 \\
2\end{array}$ & $\begin{array}{l}1 \\
2 \\
-\end{array}$ & $\begin{array}{l}4 \\
3 \\
4\end{array}$ & $\frac{2}{8}$ & $\frac{2}{3}$ & $\begin{array}{r}15 \\
9 \\
17\end{array}$ \\
\hline Total & 12 & 3 & 11 & 10 & 5 & 41 \\
\hline
\end{tabular}

Serum was available for haemagglutination tests on 22 of these patients. The relation of haemagglutination titre to dosage is shown in Table II. In general, higher titres were found in patients with large insulin requirements, and, as shown in Table III, in those whose serum showed antibody by the P.C.A. test.

\begin{tabular}{|c|c|c|c|c|c|c|}
\hline \multirow{2}{*}{$\begin{array}{c}\text { Maintenance } \\
\text { Dose } \\
\text { (units/day) }\end{array}$} & \multicolumn{5}{|c|}{ Haemagglutination Titre } & \multirow{2}{*}{ Total } \\
\hline & $<10$ & $10-$ & $80-$ & $640-$ & 5,120 & \\
\hline $\begin{array}{r}200-300 \\
300-500 \\
\text { Over } 500\end{array}$ & $\begin{array}{l}2 \\
3 \\
1\end{array}$ & $\frac{3}{1}$ & $\begin{array}{l}1 \\
1 \\
3\end{array}$ & $\frac{\bar{c}}{6}$ & $\frac{1}{-}$ & $\begin{array}{r}6 \\
5 \\
11\end{array}$ \\
\hline Total & 6 & 4 & 5 & 6 & 1 & 22 \\
\hline
\end{tabular}

TABLB III.-Relation of Haemagglutinating to P.C.A. Antibodies in 22 Resistant Diabetics

\begin{tabular}{lc|c|c|c|c|c|c}
\hline & \multicolumn{6}{|c|}{ Haemagglutination Titre } & \multirow{2}{*}{ Total } \\
\cline { 2 - 7 } & & $<10$ & $10-$ & $8 \sigma$ & 640 & 5,120 & \\
\hline P.C.A. + & $\cdots$ & 1 & 2 & 5 & 6 & 1 & 15 \\
P.C.A. - & $\cdots$ & 5 & 2 & - & - & - & 7 \\
\hline
\end{tabular}

\section{Clinical Material}

With a few exceptions the cases under review were treated in the diabetic department of King's College Hospital, London. Only patients whose daily maintenance dose of insulin exceeded 200 units for a week or more have been included. As under modern treatment ketosis never, and infection very rarely, produces insulin resistance of this duration, no patients were excluded from the present series on these grounds. The present series consists of 41 cases, in 15 of which the daily insulin requirement was between 200 to 300 units, in nine it was 301 to 500 units, and in 17 more than 500 units.

\section{Analysis of Findings}

Sex and Age at Onset of Resistance.-Of the 41 cases 20 were males and 21 females. The youngest was aged 4 years and the oldest 88 ; the mean age of the males was 49 and of the females 56 , that of the whole series being 53 . In the series of Shipp et al. (1965) the ages ranged from 12 to $74,75 \%$ being 40 or older.

Duration of Insulin Treatment Before Insulin Resistance.Three cases were resistant from within a few weeks of the onset of insulin therapy. The longest interval was 19 years and the shortest four weeks. In 21 of the 41 cases, however, the interval was 12 months or less, and in 12 was between one and six months. These findings agree closely with those of Shipp et al. (1965); the range in their series was from one month to 12 years, the duration being less than one year in $66 \%$ of cases.

Breaks in Insulin Treatment.-The incidence of interruption of insulin therapy as a result of clinical improvement, the institution of oral therapy, or the patient's whim was analysed because of its possible significance in relation to insulinantibody formation. Eight cases gave a history of one or more breaks in insulin treatment, 31 received insulin without interruption, and in two no information was available.

History of Allergy.-A history of sensitivity to proteins other than insulin was also thought to be pertinent to an immunological study of insulin resistance, but was obtained in only six cases ; 31 gave no history of allergy, and in four no information could be obtained.

In none of our cases was insulin-resistance associated with a generalized allergic reaction to insulin; nor was a history of local reaction at the site of injection of insulin more frequently obtained than in non-resistant cases. Shipp et al. (1965) reported an association between insulin allergy and insulin resistance in nearly a third of their patients ; during the treatment of insulin resistance two had widespread urticaria and one a systemic anaphylactic reaction. 
Other Factors.-The diabetes in the 41 cases was complicated by a wide variety of associated diseases, of which the most common were obesity and severe heart disease, with or without heart failure: marked obesity in 7, severe heart disease in 5, carcinoma in 3 (pancreatic in 1), and pregnancy in 2 . The onset of resistance was associated with puberty in one case and there was one instance of each of the following diseases: active rheumatoid arthritis, active tuberculosis, systemic lupus erythematosus, lymphosarcoma, fibrocystic disease of the pancreas, infantile cirrhosis, and haemochromatosis complicated by infectious hepatitis. Associated diseases were present in 10 out of 15 of the group with an insulin requirement of less than 300 units, compared with 9 out of 26 of those on higher doses. Even more striking differences are shown (Table IV) when patients with P.C.A. antibodies are compared with antibodynegative patients. Of the six antibody-negative patients receiving less than 300 units one was pregnant, three were obese, and two were at the onset of puberty.

TABLE IV.-Incidence of Associated Disease, Endocrine Disturbance, etc., and P.C.A. Antibody in Insulin Resistance

\begin{tabular}{|c|c|c|c|c|c|}
\hline \multicolumn{3}{|c|}{ P.C.A. Antibodies } & Other Factors Present & Uncomplicated & Total \\
\hline \multicolumn{6}{|c|}{ In Patients with Insulin Requirement of 200-300 Units } \\
\hline $\begin{array}{l}\text { Present } \\
\text { Absent }\end{array}$ & $\because$ & & $\begin{array}{l}4 \\
6\end{array}$ & $\begin{array}{l}5 \\
0\end{array}$ & $\begin{array}{l}9 \\
6\end{array}$ \\
\hline \multicolumn{6}{|c|}{ In Patients with Insulin Requirement of Over 300 Units } \\
\hline $\begin{array}{l}\text { Present } \\
\text { Absent }\end{array}$ & 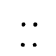 & $\because$ & \begin{tabular}{|l|}
7 \\
2
\end{tabular} & $\begin{array}{r}15 \\
2\end{array}$ & $\begin{array}{r}22 \\
4\end{array}$ \\
\hline
\end{tabular}

\section{Treatment}

All insulin-resistant cases were admitted to hospital and stabilized on a diet containing between 150 and $200 \mathrm{~g}$. of carbohydrate with free protein and fat, and morning and evening injections of soluble insulin (320 units $/ \mathrm{ml}$. strength). When a reasonably constant insulin requirement was achieved prednisone was given in a dose of $30 \mathrm{mg}$. daily ; later, if necessary, this was increased to $45 \mathrm{mg}$.

\section{Results}

\section{Cases of Resistance with P.C.A. Antibody to Insulin}

Sixteen patients in whom insulin antibodies were detected by P.C.A. were treated with prednisone in this way, and the results are shown in Fig. 1.

Corticosteroid therapy was followed in every case by a dramatic fall in insulin requirement. This occurred in all but one patient within the first 10 days of treatment ; the response in this case was more gradual and took three weeks to become maximal. Whenever possible blood was taken for estimation of P.C.A. antibody titre before and after the initial treatment

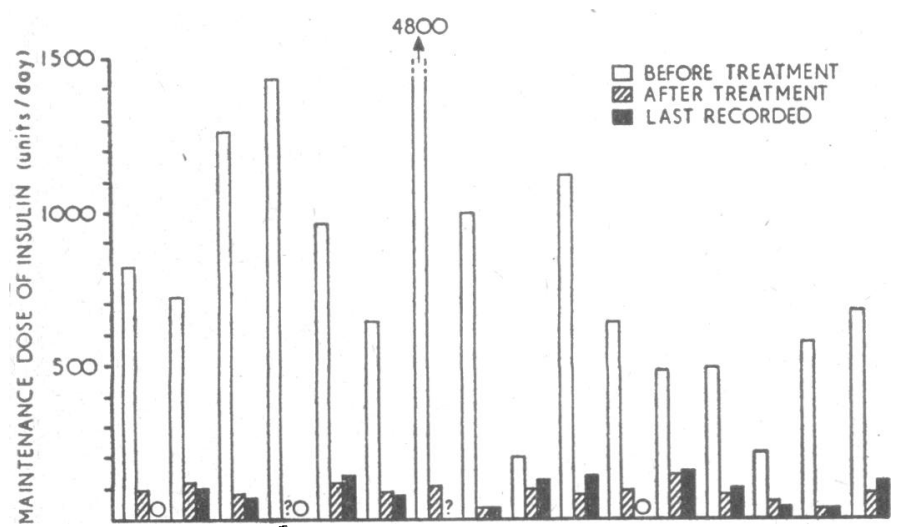

Fig. 1.-Effect of prednisone on insulin requirement in 16 cases of insulin-resistant diabetes with positive P.C.A. test. with prednisone and at a later date. The antibody level of individual patients at these times is shown in Table V, together with the insulin requirement.

Table V.-Clinical and Serological Response to Prednisone in Patients

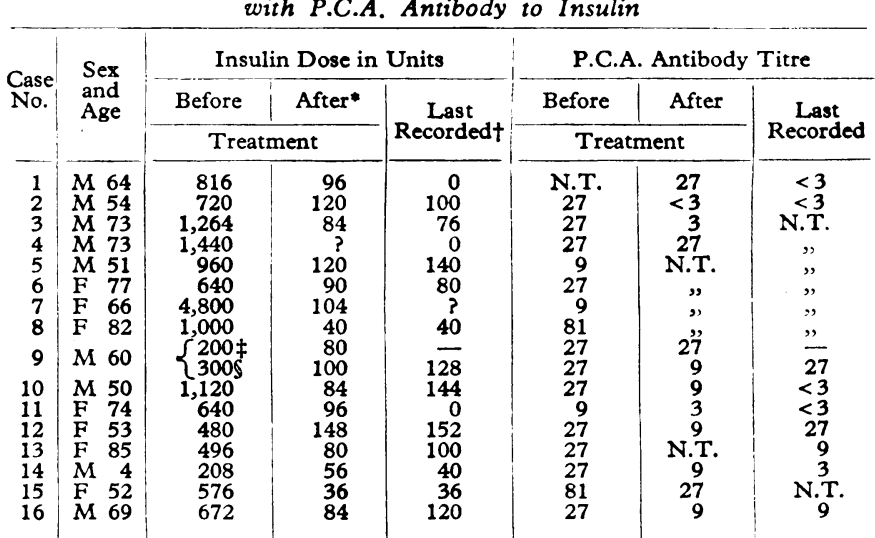

N.T. Not tested. Cases 1, 2, 3, and 4 have been described in more detail (Oakley et al., 1959)

three weeks of start of prednisone treatment.

+ Six months to three years later.

\$ First course of treatment.

In all but two cases there was a reduction, though often slight, in the P.C.A. titre immediately after the initial response to prednisone, but in five of the nine patients in whom the test was repeated at a later date there was a more significant fall. In Cases 1,4 , and 11 the patient ceased to require insulin after periods of one to four years, but the average requirement of the remainder when last seen (or at death) was 96 units, information being unobtainable in one case. In all except Case 9 corticosteroid therapy was continued at a reduced dose of 5 to $10 \mathrm{mg}$. of prednisone daily for several months, and in some cases much longer. It was found that if the prednisone was stopped too soon there was a tendency for the insulin requirement to rise. In Case 9 the prednisone was stopped after the initial response had been obtained, and the patient relapsed in five weeks but again responded to prednisone, and has since taken $5 \mathrm{mg}$. daily without relapse. It was difficult in some patients to be certain whether, after the initial response, the prednisone was not itself increasing the insulin requirement, and a reduction in dosage has occasionally been followed by a further fall in insulin.

In all cases with P.C.A. antibodies the clinical picture of insulin resistance and the response to corticosteroid therapy were generally similar and are well illustrated by Case 1 (Fig. 2).
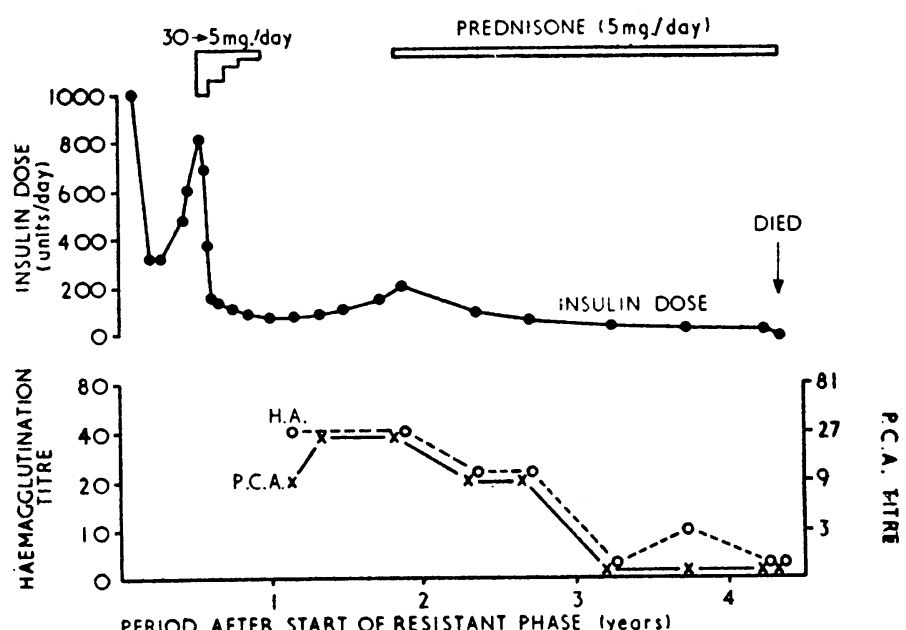

FIG. 2.-Insulin doses, corticosteroid treatment, and antibody titres in Case 1 . 
In Case 10 serum tests were carried out regularly from the onset of treatment with insulin in the course of an immunological survey, and a rising titre of both P.C.A. and haemagglutinating antibodies was found some weeks before there was any increase in insulin dosage or suspicion of insulin resistance (Fig. 3). There is therefore no question in this case of the rise in antibody being due to the administration of large amounts of insulin.

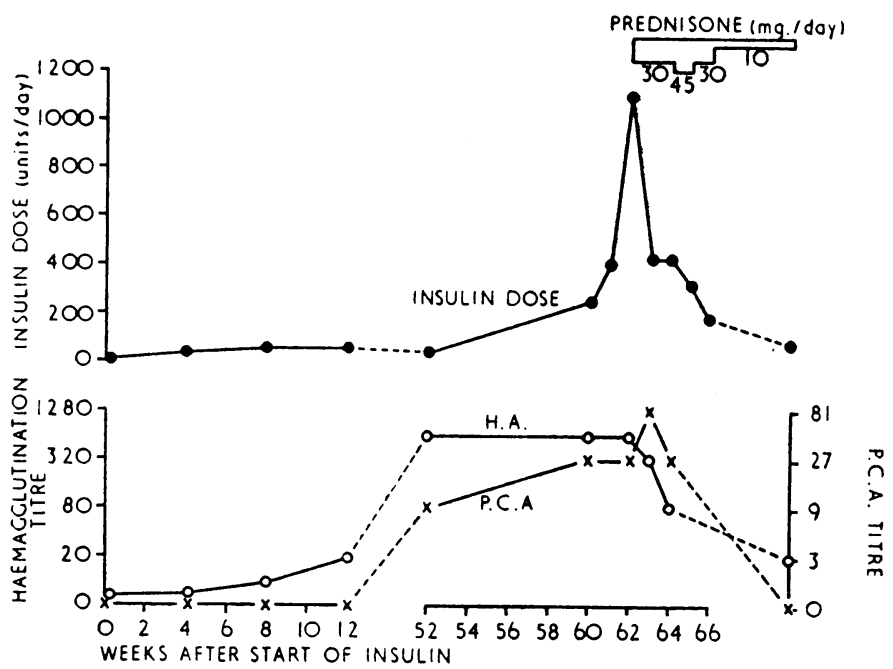

Fig. 3.-Insulin doses, corticosteroid treatment, and antibody titres in Case 10.

One patient (Case 15), whose sister was diabetic, was of interest because she developed diabetes while being treated for diffuse lupus erythematosus with prednisone in a daily dose of $20 \mathrm{mg}$. When the dose was increased to $45 \mathrm{mg}$. there was a dramatic fall in insulin requirement and reduction in P.C.A. titre.
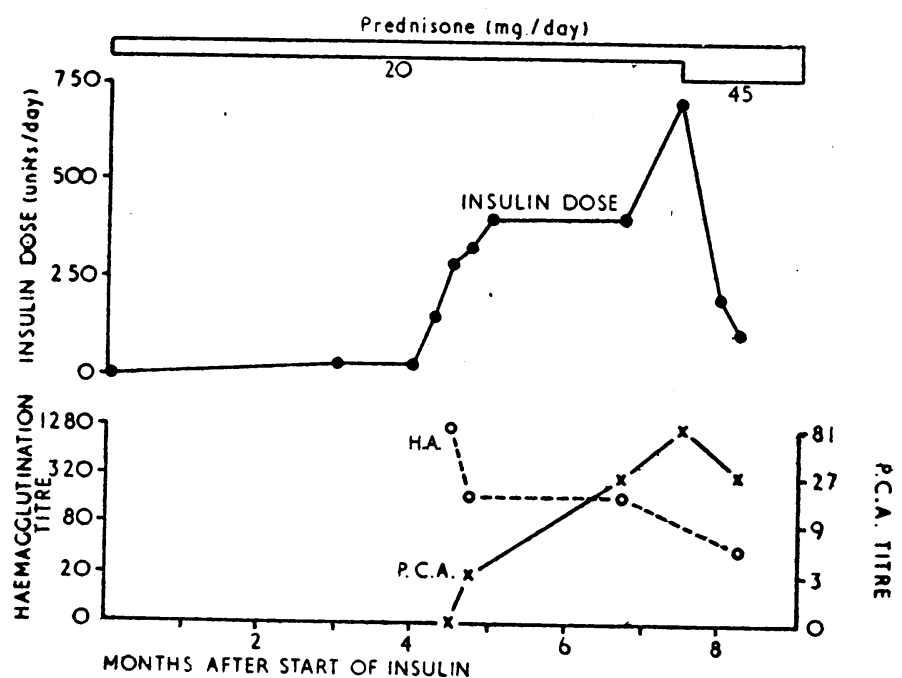

FIG. 4.-Insulin doses, corticosteroid treatment, and antibody titres in Case 15.

\section{Cases Without P.C.A. Antibody}

Four insulin-resistant diabetics with negative P.C.A. tests were treated with prednisone for periods up to three weeks and the results are shown in Fig. 5. It will be seen that in two cases there was a great increase in insulin requirement and in two no significant change. In addition to these four cases there were two patients with apparent insulin resistance and negative P.C.A. tests who also showed no response to full doses of prednisone. One, a hospital sister, was referred to us with a history of having required 900 units of insulin over a period of several months; the other, a young Irish girl, was reputed to have needed as much as 10,000 units of insulin daily to control her diabetes. In the first instance the resistance was found to be associated with the self-administration of insulin, and disappeared when the injections were given by a nurse. In the second instance the contents of the insulin phial brought by the patient contained no assayable insulin. In such cases a negative P.C.A. test may have diagnostic significance. As the insulin requirement of all P.C.A.-negative cases was either unaffected or increased by prednisone, and as there is no theoretical justification for corticosteroid therapy in these patients, the number so treated is limited to seven.

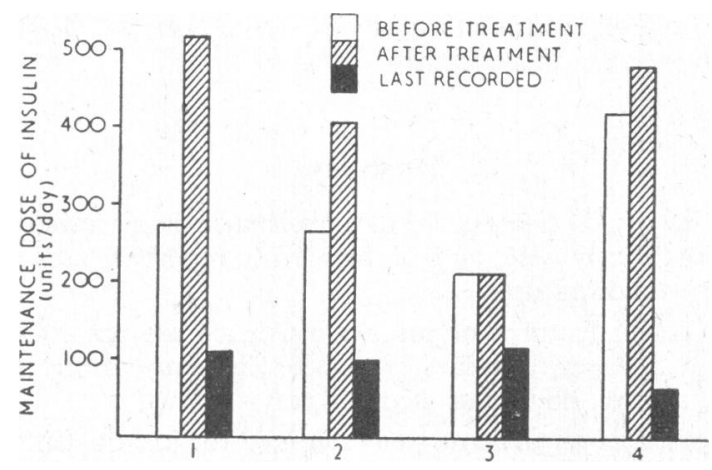

FIG. 5-Effect of prednisone on insulin requirement of four insulin-resistant diabetics with negative P.C.A. tests.

\section{Discussion}

Insulin antibodies were found by P.C.A. in 29 of the 41 cases and by haemagglutination in 15 of 22 cases of insulin resistance. The antibodies were more often present in those with higher insulin requirements. The frequency with which high titres were found was also greater in the group of patients with the higher insulin requirements; P.C.A. titres greater than 9 were found in 15 out of 17 cases requiring more than 500 units and in 18 out of 26 with requirements of more than 300 units, but in only 8 out of 15 cases receiving less than 300 units a day.

If this series of cases is representative-and we have no reason to doubt this-it is clear that there is an important and distinctive form of the comparatively rare state of insulin resistance which is associated with excessive production of insulin antibodies. The same conclusion was reached by Shipp et al. (1965). There are good reasons for believing that insulin antibodies have a causal role and are not merely part of the immunological response to the very large doses of insulin needed for treatment of the condition. Strong evidence for this is our finding in Case 10 that the appearance of antibodies preceded by some weeks an increase in insulin dosage above normal. Further, though the mode of action of corticosteroids in these cases is still far from clear, we would agree with Shipp et al. that it is difficult to explain their beneficial effect on other than immunological grounds. In our series a successful response was given by all 16 treated patients whose serum contained P.C.A. antibodies, whereas a significant rise in insulin requirement followed prednisone treatment in all four antibodynegative cases.

The hypothesis that insulin-antibody formation is an important factor in the causation of insulin resistance received further support from clinical evidence. It was noted that the diabetes of resistant patients with relatively low insulin requirements was much more frequently complicated by other factors, such as associated disease or endocrine disturbance, than was that of patients with higher degrees of resistance.

Our conclusion is that resistance requiring treatment with more than 500 units a day is seldom encountered without excessive or abnormal formation of insulin antibodies and that in these cases it is unusual to find other factors complicating 
the diabetes. This type of resistance may occur at any age, but is more frequent in the fifth decade ; the typical onset is within a year of the start (or restart) of insulin treatment. This type of resistance responds well to corticosteroid treatment. Resistance with a requirement between 200 and 300 units is seldom of the antibody type, and it is usual for associated disease or endocrine disturbance to be present. A few patients with high antibody titres were found in this group; most were seen after spontaneous remission from an episode of resistance requiring higher dosage. In the intermediate range of resistance the coexistence of increased antibody formation with other factors was a common finding. It is possible that in some cases an increase in insulin dosage for the treatment of a metabolic disturbance may stimulate antibody formation and lead to a more severe state of resistance.

\section{Summary}

A series of 41 cases of insulin resistance is reviewed; this comprises 28 new cases and 13 previously reported cases which have been followed up.

The clinical features of insulin resistance are considered in relation to age, sex, duration of diabetes, interruption in insulin therapy, allergy, and associated diseases.

The serum of all patients was examined for insulin antibodies by passive cutaneous anaphylaxis (P.C.A.) and in some cases also by haemagglutination. P.C.A. antibody was found in 29 of the 41 cases.

Treatment with corticosteroids is almost always successful in insulin resistance associated with P.C.A. antibodies and unsuccessful when the P.C.A. test is negative.

When the daily insulin requirement exceeds 300 units the insulin antibody titre is usually high and associated pathological conditions are uncommon. Patients whose requirements are less than 300 units more of ten give negative P.C.A. tests and show evidence of associated disease.

ADDENDUM.-Since the completion of this paper we have seen five further cases. In three of the patients who were P.C.A.-positive insulin resistance was successfully treated with prednisone. One patient who had a positive P.C.A. test failed to respond to prednisone, and one in whom the resistance was associated with pregnancy, but whose P.C.A. test was negative, responded well in the first pregnancy, but not in the second.

\section{REFERENCES}

Arquilla, E. R., and Stavitsky, A. B. (1956). 7. clin. Invest., 35, 458 Berson, S. A., and Yalow, R. S. (1957). Diabetes, 6, 402. Bauman, A., Rothschild, M. A., and Newerly, K. (1956). clin. Invest., 35,170

Colwell, A. R., and Weiger, R. W. (1956). 7. Lab. clin. Med., 47, 844

Field, J. B., and Stetten, D. (1956). Amer. F. Med., 21, 339

Glen, A., and Eaton, J. C. (1938). Quart. f. Med., 7, 271.

Hubble, D. (1954). Brit. med. $7 ., 2,1022$.

Jones, V. E. (1963). The Immunological Response to Exogenous Insulin, Ph.D. Thesis, London.

Ph.D. Thesis, London.
Joslin, E. P., Root, H. F., White, P., and Marble, A. (1959). The Treatment of Diabetes Mellitus, 10th ed., p. 145. Philadelphia.

Kalkhoff, R., Schalch, D. S., Walker, J. L., Beck, P., Kipnis, D. M., and Daughaday, W. H. (1964). Trans. Ass. Amer. Phycns, 77, 270.

Lawrence, R. D. (1946). Lancet, 1, 724.

Lowell, F. C. (1942). Proc. Soc. exp. Biol. (N.Y.), 50, 167.

- (1944). 7. clin. Invest., 23, 233.

Oakley, W., Field, J. B., Sowton, G. E., Rigby, B., and Cunliffe, A. C (1959). Brit, med. 7 Sowton,

Root, H. F. (1929). New Engl. F. Med., 201, 201.

Root, H. F. (1929. New

Shipp, J. C., Cunningham, R. W.,

Smelo, L. S. (1948). Proc. Amer. Diabetes Ass., 8, 75.

Vallance-Owen, J., Dennes, E., and Campbell, P. N. (1958). Lancet, 2. 336.

Yankelowitch, T., Massry, S., and Gitter, S. (1956). Diabetes, 5, 457.

Young, F. G. (1937). Lancet, 2, 372.

\title{
Effects of Cooling on the Safety of Premixed Gases
}

\author{
J. SELWYN CRAWFORD,* M.B., CH.B., F.F.A. R.C.S. ; D. B. ELLIS, † M.B., F.F.A. R.C.S. \\ D. W. HILL, $\ddagger$ M.SC., PH.D., F.INST.P., F.I.E.E. ; J. P. PAYNE, $§$ M.B., F.F.A. R.C.S., D.A.
}

Brit.med. F., 1967, 2, 138-142

The quest for an efficient and practicable method of providing the obstetric patient with nitrous oxide in a non-hypoxic mixture was prompted by the observation that some of the standard gas-and-air equipment in current use delivered considerably less than $10 \%$ oxygen (Cole and Nainby-Luxmore, 1962; Nainby-Luxmore, 1964 ; Moir and Bisset, 1965). Recently efforts have been made to satisfy this demand by providing cylinders containing a mixture of nitrous oxide and oxygen which, when combined with a suitable reducing valve, will deliver a constant proportion of oxygen (Tunstall, 1961). Later Tunstall (1963) and Gale, Tunstall, and Wilton-Davies (1964) described the limits of safety involved in the use of such a system in obstetrics. Recently apparatus designed by the British Oxygen Company has undergone limited clinical trial in both domiciliary and hospital practice, and has been approved by the Central Midwives Board for use by midwives (Lancet, 1965). Cole (1964), however, has produced evidence to suggest

* Deputy Director and Senior Leverhulme Fellow.

+ Dräger Research Fellow.

- Senior Lecturer in Medical Physics.

British Oxygen Professor of Anaesthesia.

Research Department of Anaesthetics, Royal College of Surgeons of England, London W.C.2. that the use of premixed gases is more hazardous than had been believed. His observations on the response of premixed gases to cold and some apparent anomalies in the published data on the influence of temperature change (Tunstall, 1963 ; Gale et al., 1964) invited further investigation. Accordingly, the present study was undertaken.

\section{Material and Methods}

The primary objective of the investigation was to study the effect of cold upon the composition of the gas mixture obtained from a cylinder during the entire period of emptying.

Eighty cylinders containing a $50 / 50 \%$ nitrous oxide and oxygen mixture were studied. Of the cylinders studied 60 were small and contained 500 litres of gas mixture; the remaining 20 large cylinders contained 2,000 litres. On each occasion the cylinder was full at the beginning of the formal " run," which was concluded only when the cylinder had been completely emptied.

Storage and Cooling.-Sixty-five cylinders lying horizontally were cooled for between 12 and 72 hours in one of two ways. 